African Crop Science Journal by African Crop Science Society is licensed under a Creative Commons Attribution 3.0 Uganda License. Based on a work at www.ajol.info/ and www.bioline.org.br/cs DOI: https://dx.doi.org/10.4314/acsj.v28i1.3S

\title{
PHYSICO-CHEMICAL PROPERTIES AND SENSORY QUALITY OF CASSAVA-COWPEA-MILLET COMPOSITE FLOURS
}

\author{
S.O. ONYANGO, G.O. ABONG, M.W. OKOTH, D. KILALO' ${ }^{1}$ and A.W. MWANG'OMBE ${ }^{1}$ \\ Department of Food Science, Nutrition and Technology, University of Nairobi, P. O. Box 29053, \\ 00625, Nairobi, Kenya \\ ${ }^{1}$ Department of Plant Science and Crop protection, University of Nairobi, P. O. Box 29053, 00625, \\ Nairobi, Kenya \\ Corresponding author email: samwelonyango27@gmail.com
}

\begin{abstract}
There is global increase in demand for good health and nutrition. The objective of this study was to formulate nutritious composite flours from cassava (Manihot esculenta L.) roots, cowpea (Vigna unguiculata) leaves, and millet (Pennisetum glaucum), especially for children and expectant women. A Nutrisurvey software was used to formulate three flour products, namely 20:50:30, 10:50:40 and 15:60:25 of cassava roots, cowpea leaves, and millet, respectively to achieve more than $40 \%$ daily requirement of protein, iron and zinc for the expectant woman. The products were subjected to a sensory panel and evaluated against a standard commercial flour (Famila) sold in the Kenyan market. The flours were also subjected to accelerated shelf-life study based on physico-chemical properties and growth of yeast and molds. Results indicated that 20:50:30 and 10:50:40 had the highest colour scores on a 7-point hedonic scale, 5.2 \pm 1.35 and $5.2 \pm 1.48(\mathrm{P}<0.05)$. The score indicates a near equal acceptability of the flour based on colour for both the standard. The green porridge $(15: 60: 25)$ was the least accepted flour and had the highest total aerobic count of $3.7 \mathrm{log} \mathrm{cfu} \mathrm{g}^{-1}$ after four months of storage. The acid value of the flours ranged from as low as $1.84 \pm 0.01 \mathrm{mg} \mathrm{KOH} \mathrm{g}^{-1}$ for the 20:50:30 at day zero and as high as $12.9 \pm 1.73 \mathrm{mg} \mathrm{KOH} \mathrm{g}^{-1}$ after six months of storage. The formulated 20:50:30 flours

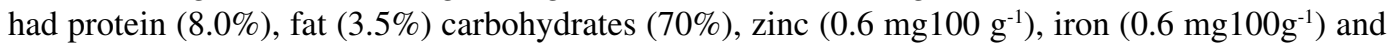
vitamin $\mathrm{C}\left(0.3 \mathrm{mg} 100 \mathrm{~g}^{-1}\right)$.
\end{abstract}

Key Words: Iron, pregnant mothers, protein, zinc

\section{RÉSUMÉ}

Il y a une augmentation mondiale de la demande d'une bonne santé et d'une bonne nutrition. L'objectif de cette étude était de formuler des farines composites nutritives à partir de racines de manioc (Manihot esculenta L.), de feuilles de niébé (Vigna unguiculata) et de mil (Pennisetum glaucum), en particulier pour les enfants et les femmes enceintes. Un logiciel Nutrisurvey a été utilisé pour formuler trois produits à base de farine, à savoir 20:50:30, 10:50:40 et 15:60:25 de racines de manioc, de feuilles de niébé et de millet, respectivement, pour atteindre plus de $40 \%$ des besoins quotidiens en protéines, fer et zinc pour la femme enceinte. Les produits ont été soumis à un panel sensoriel et évalués par rapport 
à une farine commerciale standard (Famila) vendue sur le marché au Kenya. Les farines ont également été soumises à une étude de durée de conservation accélérée basée sur les propriétés physicochimiques et la croissance des levures et des moisissures. Les résultats ont indiqué que 20:50:30 et 10:50:40 avaient le couleur les plus élevés sur une échelle hédonique à 7 points, 5,2 $\pm 1,35$ et 5,2 $\pm 1,48$ ( $\mathrm{P}<0,05)$. L'échelle hédonique indique une acceptabilité presque égale de la farine sur la base de la couleur pour le standard. La bouillie verte (15:60:25) était la farine la moins acceptée et avait le compte aérobie total le plus élevé de $3,7 \mathrm{log}$ ufc $\mathrm{g}^{-1}$ après quatre mois de stockage. L'indice d'acide des farines variait entre $1,84 \pm 0,01 \mathrm{mg} \mathrm{KOH} \mathrm{g}^{-1}$ pour le 20:50:30 au jour zéro et jusqu'à $12,9 \pm 1,73 \mathrm{mg} \mathrm{KOH} \mathrm{g}^{-1}$ après six mois de stockage. Les farines formulées à 20:50:30 contiennent des protéines $(8,0 \%)$, des lipides $(3,5 \%)$, des glucides $(70 \%)$, du zinc $\left(0,6 \mathrm{mg} 100 \mathrm{~g}^{-1}\right)$, du fer $\left(0,6 \mathrm{mg} 100 \mathrm{~g}^{-1}\right)$ et de la vitamine $\mathrm{C}(0,3 \mathrm{mg} 100$ $\left.\mathrm{g}^{-1}\right)$.

Mots Clés: Fer, femmes enceintes, protéines, zinc

\section{INTRODUCTION}

Cassava (Manihot esculenta L.) is a drought resistant root crop that is a rich source of starch for human and livestock consumption, and industrial purposes. It currently feeds over 800 million people in the world (Abong et al., 2016). The Kenyan government, in its BIG FOUR agenda, promotes cassava as a potential food security crop, an industrial game changer and a crop with diverse potential for creation of employment (Odhiambo et al., 2018). The crop is grown with other legumes, such as cowpea, pigeon pea mainly by smallscale farmers and beans as intercrops (IITA, 2016). Thus, in an attempts to achieve a food and nutrition secure Africa, it becomes important to create nutritious meals targeting fortification of such locally available crops to meet the nutrition needs of consumer communities. Such a move shall ensure massive reduction in the cost of accessing nutritious meals by consumer households (Senevirathne et al., 2016).

There has been a trend in Kenya to promote the use of composite flours which are protein and mineral enriched, from locally grown tropical legume crops and other cereals crops for minerals such as zinc and iron (Muoki et $a l ., 2015)$. The quality of the products that are made from such root-legume cereal combinations depend on the individual proportions of the primary constituents of the flours, as well as the targeted consumers (Muoki et al., 2015; Lansakara et al., 2016)

Millet and cowpea leaves are rich sources of proteins, zinc, iron and vitamins $\mathrm{A}$ and $\mathrm{C}$ (Okonya and Maass, 2014; Singh, 2016). The formulation of a composite flour of cassava roots, millet and cowpea leaves shall ensure that the special groups, expectant and lactating women, and children get access to a high nutrient meal in one serving. This study sought to document the physico-chemical properties, acceptability and keeping quality of protein and mineral enriched cassava-cowpea-millet leaves composite flours from selected cassava varieties grown at the Kenyan coast.

\section{MATERIALS AND METHODS}

Preparation of cassava flours. Cassava roots from variety, Tajirika, that was found to retain the most nutrients when compared with Kibandameno and Kaleso (Onyango, 2019), were collected from farms in Kilifi County, along the Kenyan coast; and mixed together. The samples, $3 \mathrm{~kg}$ of root per farm from 4 different farms, were harvested at maturity and transported overnight to the University of Nairobi, Food Chemistry Laboratory. The roots were washed using clean tap water, to remove adhering soil. The cleaned roots were then manually peeled using a knife, before being dipped in potable water in a bucket and washed. The roots were divided in two 
portions; the first portion was sliced into approximately 20-30 $\mathrm{mm}$ slices and oven-dried at $60^{\circ} \mathrm{C}$ for 24 hours. The dried chips were then milled into fine flour, using a locally fabricated flour miller, giving fine flour passing through 212-mm sieve. The second portion of the roots were soaked in potable water, and put in sacks, and the sacks hanged to allow the water to drip while fermenting for 3 days. The fermented roots were then sliced into 20$30 \mathrm{~mm}$ thick slices and oven-dried at $60{ }^{\circ} \mathrm{C}$ for 24 hours, before milling into fine flour passing through 212-mm sieve. The flours were then used to formulate composite flours for sensory evaluation using Nutrisurvey software.

Preparation of millet flours. Dried pearl millet grains were collected from six farms in Kilifi county, the grains sorted to remove chaffs and sieved to obtain clean quality grains. The grains were milled using a locally fabricated mill, into fine flour to pass through 212-mm sieve and the flour fermented for 48 hours after soaking in potable water in the mass ratio of 2 water and 3 flour and sealing tightly. The flour was then sun-dried, ready for use for the development of composite flour blends. Millet is a good source of zinc and iron (Singh, 2016; Adebeyi et al., 2017) which are target nutrients for the composite flour.

Preparation of cowpea leaves flour. Cowpea (Vigna unguiculata) leaves, M66 variety in Kenya were grown at the University of Nairobi field station farm, under standard agronomic practices, timely watering, minimisation of pests, and fertiliser application. The cowpea leaves were harvested at the end of week 4 and at the end of each subsequent week till week 8 . The samples were fermented using sauerkraut technology (Zabat et al., 2018). The fermented cowpea leaves were dried and then milled into fine flour passing through 212$\mathrm{mm}$ sieve, for use in making of composite flours. Cowpea leaves are a rich source of protein, vitamins $\mathrm{A}$ and $\mathrm{C}$ and minerals zinc and iron (Okonya et al., 2014).

Formulation of composite flours. The study used a Nutrisurvey software developed by Jürgen and Breind in October 2014, for linear programming, to generate the corresponding proportions of cassava roots, cowpea leaves and millet. The nutrients optimised were protein, fat, zinc, iron, calcium, and vitamins $A$ and $C$. The optimisation was done to ensure that each formulation provided more than $40 \%$ of the daily recommended intake in a single meal for expectant women. The three blends were formulated in triplicates as shown in Table 1.

\section{Analytical methods}

\section{Determination of proximate composition}

Moisture content. The moisture content of the raw samples and different flour blends were determined as per AOAC (2016) method number 934.01. About $5 \mathrm{~g}$ of each sample was taken into a dish, the dish and its contents were then put in an air oven maintained at 105 ${ }^{\circ} \mathrm{C}$ and left to dry for 4 hours. The samples were cooled in a desiccator and weighed. The dishes were then returned to the oven and dried until the moisture content variation was within $0.05 \%$. The moisture content of the sample

TABLE 1. Formulations of cassava, millet and cowpeas leaves flour blends

\begin{tabular}{lccc}
\hline Flour formulations & Cowpea leaves $(\%)$ & Cassava roots flour (\%) & Millet flour $(\%)$ \\
\hline$(20: 50: 30)$ & 20 & 50 & 30 \\
$(10: 50: 40)$ & 10 & 50 & 40 \\
$(15: 60: 25)$ & 15 & 60 & 25 \\
\hline
\end{tabular}


was then calculated as a percentage of the sample weight.

The moisture content of the raw cassava samples and different flours were determined as per AOAC (2016) method number 934.01. About $5 \mathrm{~g}$ of each of sample was taken and oven dried at $80{ }^{\circ} \mathrm{C}$ for a period of 4 hours. The dried samples were later re-weighed and the percentage weight loss determined. The percentage weight loss was expressed as the percentage moisture content of the respective flours.

Crude ash content. Ash content was determined as per AOAC (2016) Method number 923.03. About $2 \mathrm{~g}$ of each sample was weighed into a tared porcelain crucible; and ashing started with low burning Bunsen burner flame. The ashing process was then continued in a muffle oven at $500{ }^{\circ} \mathrm{C}$ until a light grey ash of constant weight was obtained. The ash content of the sample was then calculated and expressed as a percentage of the sample weight.

Crude protein content. Crude protein content was determined as per AOAC (2016) method number 992.15. Approximately $0.5 \mathrm{~g}$ of each sample was taken in a nitrogen-free filter paper folded carefully and placed in a Kjedahl flask together with anti-burning pumice. One Kjedahl catalyst tablet and concentrated sulphuric acid was added and the mixture heated slowly in a fume cupboard until a clear solution was obtained. The boiling continued for 1 hour. The mixture was then cooled and a few drops of phenolphthalein added. A $400 \mathrm{ml}$ conical flask containing 50 $\mathrm{ml}$ of $0.1 \mathrm{~N} \mathrm{HCl}$ solution with some added methyl orange indicator, was placed under the outlet of the distillation unit. Just enough $40 \%$ $\mathrm{NaOH}$ solution was added to change the colour of the solution and the mixture distilled until a drop of distillate did not react with Nessler's reagent placed in a test-tube. Back titration was then done with $0.1 \mathrm{~N} \mathrm{NaOH}$ solution and the crude protein content of the sample calculated as a percentage of the sample weight.

Crude fibre content. Crude fibre content was determined according to AOAC (2016) method number 985.29. Approximately $2 \mathrm{~g}$ of the flours were weighed into a graduated $600 \mathrm{ml}$ beaker and a small amount of boiling water and $25 \mathrm{ml}$ of $2.04 \mathrm{~N}$ sulphuric acid solution added. The volume of the solution was topped to $200 \mathrm{ml}$ and maintained while boiling for 30 minutes. The contents of the beaker were then filtered using a Buchner funnel slightly packed with glass wool and the residue washed.

The residue together with the glass wool were then transferred into the beaker and a small amount of distilled water and $25 \mathrm{ml}$ of $1.73 \mathrm{~N} \mathrm{KOH}$ solution added, the volume was topped to $200 \mathrm{ml}$ with boiling distilled water and heated for 30 minutes. The solution was again filtered using a glass wool.

The residue was transferred quantitatively into a porcelain dish and dried in an air oven set at $105{ }^{\circ} \mathrm{C}$ for 2 hours. The desiccator was then cooled and weighed. The dish contents were ignited at $550{ }^{\circ} \mathrm{C}$ before cooling and weighing. The crude fibre content of the samples were then calculated as percentage of the sample weight.

Crude fat content. Crude fat content was determined as per AOAC (2016) method number 920.39 . About $5 \mathrm{~g}$ of the flours were taken into an extraction thimble and covered with a cotton wool, and placed in a sohxlet extractor. The tared flat bottomed flask, with $200 \mathrm{ml}$ of petroleum ether, was then placed on a heating mantle and connected to the sohxlet extractor for 8 hours. The solvent was then evaporated in a rotary evaporator, the residue dried in an air oven set at $105{ }^{\circ} \mathrm{C}$ for 1 hour and the crude fat content expressed as a percentage of the sample weight. 
Carbohydrates content. Carbohydrates content was determined as per AOAC (2016) by the difference, i.e. $100 \%$ minus the total sum of fat, moisture content, crude fibre, Ash and proteins in $100 \mathrm{~g}$ of food.

Energy content. The energy content of the food samples in wet weight forms was determined using the conversion formula as described FAO (2003) in a final energy conversion report (FAO, 2003). The formula entailed a conversion rate of $4 \mathrm{kcalg}^{-1}$ for protein and carbohydrates and $9 \mathrm{kcalg}^{-1}$ for fats.

Mineral content. The mineral content was determined as per AOAC (2016) by method number 985.27, for both zinc and iron. The mineral contents were read on an Atomic Absorption Spectrophotometer (buck Scientific 210 VGP, USA).

Shelf-life of composite flours. The accelerated shelf-life of the composite flours was determined as per AOAC (2016) method. About $100 \mathrm{~g}$ of each flour sample was weighed and packaged in craft paper, which currently is the standard storage container for commercial flours in Kenya, following the Governments ban on use of polythene as packages. The corresponding flour samples were then incubated at $55^{\circ} \mathrm{C}$ for 7 days, and samples picked for microbial analysis (yeast and molds) and analysis of peroxide and acid value to determine the shelf-life of the formulated flours.

Peroxide value. The peroxide value was determined as per AOAC (2016) method number 965.33. About $5 \mathrm{~g}$ of each flour sample was weighed in a $300 \mathrm{ml}$ glass stoppered conical flask. Then $30 \mathrm{ml}$ of the mixture of glacial acetic acid and chloroform in the ratio of 3:1 was added; and $0.5 \mathrm{ml}$ of saturated KI solution was added to the mixture. The solution stood in the dark for about 1 minute, while occasionally shaking, before 30 $\mathrm{ml}$ of distilled water was added. The solution was titrated against $0.01 \mathrm{~N}$ sodium Thiosulphate, after addition of about $0.5 \mathrm{ml}$ of $1 \%$ starch solution, until the blue colour disappeared. The peroxide value (PV) was computed using the following formula:

$\mathrm{PV}=1000(\mathrm{~b}-\mathrm{a}) \mathrm{N} / \mathrm{w}$ (in milliequivalents of peroxide oxygen per $\mathrm{kg}$ )

Where:

$\mathrm{a}=\mathrm{ml}$ of sodium thiosulphate for the blank;

$\mathrm{b}=\mathrm{ml}$ of sodium thiosulphate for the sample;

$\mathrm{w}=$ weight of the sample; and

$\mathrm{N}=$ normality of the Sodium thiosulphate solution.

Acid value of composite flour. The acid value of composite flours was determined as per AOAC method number 993.25. About $3 \mathrm{~g}$ of flour per sample was taken into $200 \mathrm{ml}$ conical flask. Then $40 \mathrm{ml}$ of the solvent mixture of benzene and ethanol in the ratio of $1: 2$ were added and titrated with $0.1 \mathrm{~N}$ alcoholic $\mathrm{KOH}$ solution against phenolphthalein indicator. The Acid value was computed as follows:

$\mathrm{AV}=\frac{-5.611(b-a)}{W}$

Where:

$\mathrm{AV}=$ Acid value;

$\mathrm{a}=\mathrm{ml}$ of alcoholic $\mathrm{KOH}$ used for blank;

$\mathrm{b}=\mathrm{ml}$ of alcoholic $\mathrm{KOH}$ used for the sample; and

$\mathrm{w}=$ weight of the sample.

Microbial quality of stored composite flour blends. Composite flour samples were held under accelerated conditions of $55^{\circ} \mathrm{C}$ (one day of storage is equal to 1 month of storage at 25 ${ }^{\circ} \mathrm{C}$ ) and subsequently after every 24 hours for 5 days. About $10 \mathrm{~g}$ of each flour formulation was taken into $90 \mathrm{ml}$ of diluent $(0.85 \%$ sodium chloride solution); followed by serial dilutions 
to $10^{\wedge}-3$. About $1 \mathrm{ml}$ of the dilutions was placed each in a petri dish and about $15 \mathrm{ml}$ of acidified potato dextrose agar for yeast and moulds. For total viable count, $15 \mathrm{ml}$ of plate count agar was added using sterilised pipette. The samples were then incubated at $37^{\circ} \mathrm{C}$ for total viable count; while for yeast and moulds the oven temperatures were set at $30^{\circ} \mathrm{C}$. The incubation for total viable count was monitored at 24 hours; while for yeast and mould the incubation time was 48 hours. Colony count was done using the colony counter and the results expressed by multiplying by the dilution factor of the plate counted. The analyses were done in duplicates.

Sensory evaluation. Sensory evaluation was done for the 3 formulated green porridge prepared from the blended flours, against the already commercialised Famila porridge flour brand. The four porridges were cooked as follows: three litres of water was put in a cooking pot and allowed to boil for about 3 minutes. Approximately $600 \mathrm{~g}$ of flour was mixed with 2 litres of cold potable water to form a slurry. Then the slurry was added to the boiling water till the desired consistency and cooking flavour for about 5 minutes.

Four table spoonful of brown sugar were added to the porridge. The four porridge types were coded as FAMILA, 20:50:30, 10:50:40, and 15:60:25 and were presented for sensory evaluation to a panel of 50 farmers ( 30 females and 20 males), who were primary consumers of cassava flours; and were willing to take part in the sensory evaluation (Kayitesi et al., 2010). The panellists were taken through a short training on how to score for texture, colour, taste and aroma of the varied porridge samples. The study used a 7 point hedonic scale scoring; 1 for very much disliked, 2 for much disliked, 3 for disliked, 4 for liked and did not like, 5 for liked, 6 for liked a lot, 7 for very much liked (Mwizerwa et al., 2017).

Data analysis. The data were analysed using Stastical Package for Social Sciences (SPSS) software version 21 for the analysis of variance
(ANOVA) and the means were separated by the least significant difference at $\mathrm{P}<0.05$.

\section{RESULTS}

Proximate composition of blended flours. The nutritional composition of the four flour formulation was significantly different $(\mathrm{P}<0.05)$ among the formulations (Table 2). The 10:50:40 had the highest moisture content (9.84\%); while 20:50:30 had the lowest moisture content. Mean fibre content of the formulated flours was 5.3\%, with 20:50:30 having the highest amounts at $5.8 \%$; while 10:50:40 had the lowest fibre content (4.9\%). There was no significant $(P>0.05)$ variation in ash content of the three formulated flours.

The flour formulations had significantly higher levels of proteins, when compared to FAMILA the control, though there were no significant $(\mathrm{P}>0.05)$ differences between the formulations. Overall the 20:50:30 had high levels of protein (at 9\%). For formulations 10:50:40 and 15:60:25, the protein content was the lowest (at 8\%).

Carbohydrate contents of the three formulated flours were significantly $(\mathrm{P}<0.05)$ different between the formulations. Carbohydrate content was high in formulation 15:60:25(72.43\%) and the least in 20:50:30 $(69.4 \%)$. The formulated flours were high in energy, averaging at $352.6 \mathrm{kcal} 100 \mathrm{~g}^{-1}$ wet weight.

Mineral and vitamin contents. The minerals and vitamin levels of the three formulated flour blends are presented in Table 3. Formulation 10:50:40 had the highest level of iron of 0.6 mg $100 \mathrm{~g}^{-1}$; while formulation 15:60:25 had the lowest levels $\left(0.5 \mathrm{mg} 100 \mathrm{~g} \mathrm{~g}^{-1}\right)$ of this element. The zinc levels of the three formulations averaged at $63.0 \mathrm{mg} 100 \mathrm{~g} \mathrm{~g}^{-1}$, with the highest in 20:50:30 and 10:50:40 (0.65 $\left.\mathrm{mg} 100 \mathrm{~g}^{-1}\right)$ and the lowest in 15:60:25 (0.6 $\left.\mathrm{mg} 100 \mathrm{~g} \mathrm{~g}^{-1}\right)$. The levels of vitamin A were the

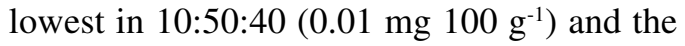

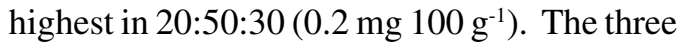
flour blends had significantly $(\mathrm{P}<0.05)$ 
different levels of Vitamin C, being the highest in 10:50:40 (0.25 mg $\left.100 \mathrm{~g}^{-1}\right)$ and the lowest in 20:50:30 (0.23 mg $\left.100 \mathrm{~g}^{-1}\right)$.

Sensory evaluation. The most appealing colour was in FAMILA and formulation 20:50:30, with sensory scores of $5.18 \pm 1.35$ and 5.18 \pm 1.48 , respectively (Table 4 ). There was no significant difference $(\mathrm{P}>0.05)$ in the sensory scores of the mouth feel. Formulation 10:50:40 was the least acceptable $(\mathrm{P}<0.05)$ in general. Based on seven scale hedonic score, the sensory evaluation scores were significantly different $(\mathrm{P}<0.05)$ in terms of colour, flavour, texture and general acceptability. Formulation 20:50:30 had the highest colour score of $5.18 \pm 1.48$; while 15:60:25 had the least score 4.50 \pm 2.10 .

The flavour score was also significantly different $(\mathrm{P}<0.05)$; with 20:50:30 having the highest score 5.52 \pm 1.54 ; and 15:60:25 with the least score of $4.68 \pm 1.88$. The texture scores of the four composite porridges were also significantly different between the flours. The highest score was in FAMILA $(5.32 \pm 1.25)$; while 10:50:40 had the least score $(4.60 \pm 1.69)$. For general acceptability of the four flours, formulation 20:50:30 had the highest score $(5.50 \pm 1.33)$.

Microbial counts. Figure 1 illustrates the total viable microbial counts of over a six months storage period. The total viable microbial counts decreased with storage time in all the three samples as shown in Figure 1. Flour formulation 15:60:25 had the highest microbial counts (3.74 log $\mathrm{cfu} \mathrm{g}^{-1}$ ) during storage as shown in Figure 1.

Physico-chemical properties. The formulated flours (Fig. 1) had significant variation of moisture content of flours 20:50:30, 10:50:40 and 15:60:25 during 5 days storage at $55^{\circ} \mathrm{C}$; which is equivalent to storage for 5 months at ambient temperature $\left(25^{\circ} \mathrm{C}\right)$. The moisture content of the 3 varied flour compositions averaged $11.23 \pm 0.16 \%$ on day one, and on storage, the flour moisture contents dropped 
TABLE 3. Vitamins and mineral quantities in the formulated flour blends of cassava, cowpea and millet leaves

\begin{tabular}{|c|c|c|c|c|}
\hline \multirow[t]{2}{*}{ Formulations } & \multicolumn{2}{|c|}{ Minerals } & \multicolumn{2}{|c|}{ Vitamins } \\
\hline & $\begin{array}{c}\mathrm{Fe} \\
\left(\mathrm{mg} 100 \mathrm{~g}^{-1}\right)\end{array}$ & $\begin{array}{c}\mathrm{Zn} \\
\left(\mathrm{mg} 100 \mathrm{~g}^{-1}\right)\end{array}$ & $\begin{array}{l}\text { Vitamin A } \\
\left(\mathrm{mg} 100 \mathrm{~g}^{-1}\right)\end{array}$ & $\begin{array}{l}\text { Vitamin C } \\
\left(\mathrm{mg} 100 \mathrm{~g}^{-1}\right)\end{array}$ \\
\hline 20:50:30 & $0.54 \pm 0.02$ & $0.65 \pm 0.01$ & $0.02 \pm 0.001$ & $0.23 \pm 0.001$ \\
\hline 10:50:40 & $0.63 \pm 0.01$ & $0.65 \pm 0.01$ & $0.01 \pm 0.005$ & $0.25 \pm 0.005$ \\
\hline 15:60:25 & $0.52 \pm 0.02$ & 0.600 .02 & $0.02 \pm 0.005$ & $0.25 \pm 0.005$ \\
\hline Mean & 0.56 & 0.63 & 0.016 & 0.24 \\
\hline $\begin{array}{l}\mathrm{LSD}(\mathrm{P}<0.05) \\
\mathrm{CV}(\%)\end{array}$ & 0.08 & 0.14 & 0.008 & 0.03 \\
\hline P-value & 0.6 & 1.0 & 2.7 & 0.6 \\
\hline
\end{tabular}

TABLE 4. Sensory evaluation scores on a 7-point hedonic scale for porridge made from the cassavacowpea-millet composite flours

\begin{tabular}{lllllc}
\hline Samples & Colour & Flavour & Mouthfeel & Texture & $\begin{array}{c}\text { General } \\
\text { acceptability }\end{array}$ \\
\hline FAMILA(Control) & $5.18 \pm 1.35^{\mathrm{b}}$ & $5.04 \pm 1.92^{\mathrm{ab}}$ & $5.08 \pm 1.46^{\mathrm{a}}$ & $5.32 \pm 1.25^{\mathrm{c}}$ & $5.16 \pm 1.35^{\mathrm{ab}}$ \\
$20: 50: 30$ & $5.18 \pm 1.48^{\mathrm{b}}$ & $5.52 \pm 1.54^{\mathrm{b}}$ & $5.10 \pm 1.67^{\mathrm{a}}$ & $5.10 \pm 1.68^{\mathrm{bc}}$ & $5.50 \pm 1.33^{\mathrm{b}}$ \\
$10: 50: 40$ & $4.46 \pm 1.80^{\mathrm{a}}$ & $4.68 \pm 1.88^{\mathrm{a}}$ & $4.60 \pm 1.69^{\mathrm{a}}$ & $4.40 \pm 1.57^{\mathrm{ab}}$ & $4.78 \pm 1.60^{\mathrm{a}}$ \\
$15: 60: 25$ & $4.50 \pm 2.10^{\mathrm{a}}$ & $4.72 \pm 1.93^{\mathrm{ab}}$ & $4.42 \pm 1.94^{\mathrm{a}}$ & $4.48 \pm 1.56^{\mathrm{a}}$ & $4.86 \pm 1.82^{\mathrm{ab}}$ \\
\hline
\end{tabular}

FAMILA = common retailed famila flour; 20:50:30, 10:50:40 and 15:60:25 = proportion of cowpea leaves, cassava roots and millet percent composition, respectively

significantly $(\mathrm{P}<0.05)$ for the first two days before steadily rising from the third to the fifth day. The moisture contents of the three flour blends were significantly different between the samples and between the storage days $(\mathrm{P}<0.05)$. Major variations occurred on the third day of storage, with FAMILA having the lowest moisture content; while the 20:50:30 flour formulation had a high level of $2.34 \pm 0.03 \%$. The moisture contents initially decreased until days 4-5 when it surged up. FAMILA was not considered for microbial analysis since it was a commercialised flour already retailed in the market.
Figure 3 shows variation of acid value of flour formulations for 20:50:30, 10:50:40 and 15:60:25 during storage for 5 days at $55^{\circ} \mathrm{C}$, equivalent to storage for 5 months at ambient temperature. The acid values of the three formulations were significant and increased from 2.65, 1.84 and $2.09 \mathrm{mg} \mathrm{KOHg}^{-1}$ on day 0 to $23.19,30.27$ and $27.90 \mathrm{mg} \mathrm{KOHg}^{-1}$ on day 5, respectively. On days 1 and 2, 20:50:30 had the lowest acid value; while FAMILA had the highest acid value. However, on days 3, 4 and 5, FAMILA had the lowest acid value; while 20:50:30 had the highest acid value. 


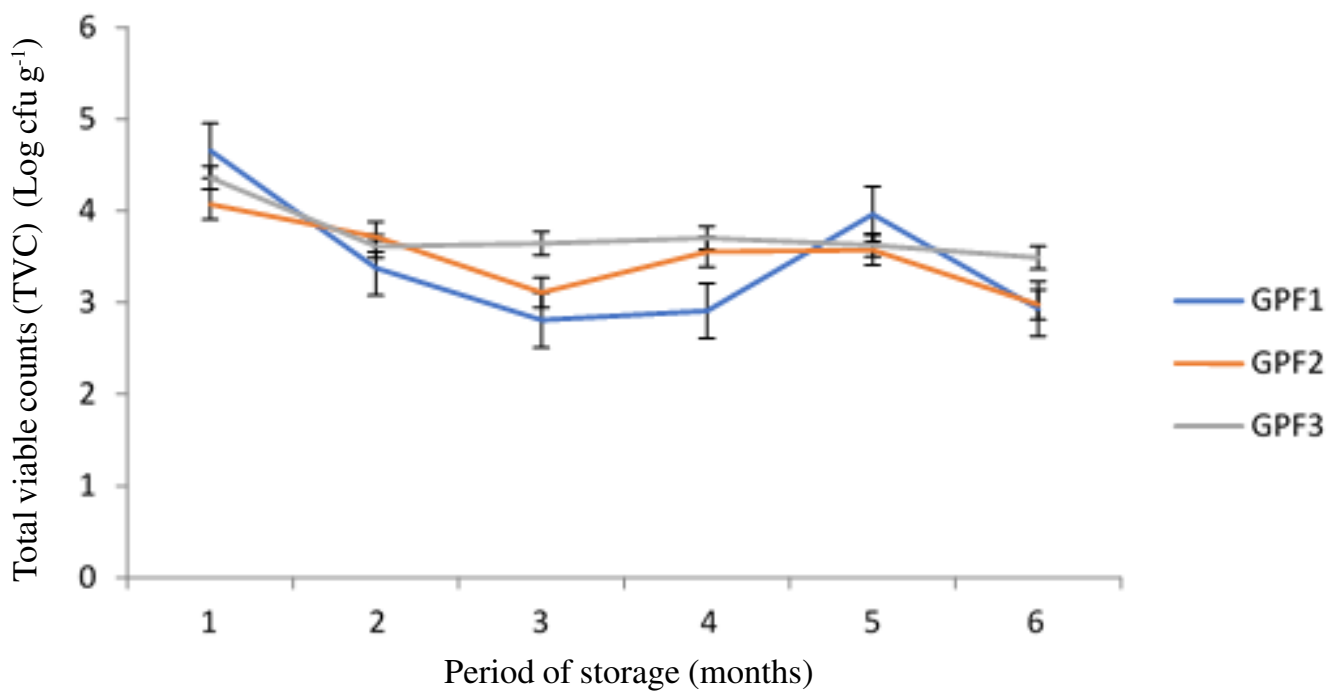

Figure 1. Total aerobic microbial countsfor three flour blends of cassava, cowpea and millet leaves.

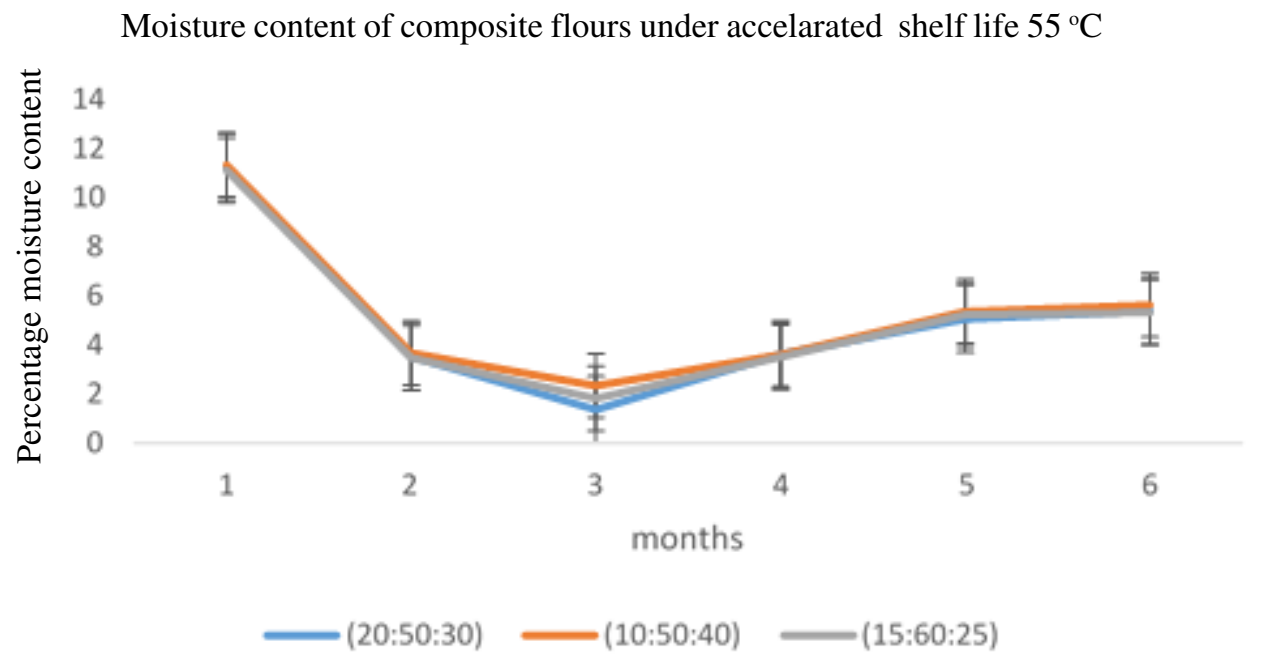

Figure 2. The moisture content of composite flours under accelerated shelf life $55^{\circ} \mathrm{C}$.

\section{DISCUSSION}

Nutritional composition of flour blends. The cassava roots-cowpea leaves and millets flour blends formulated, had higher protein content $(9.0 \mathrm{~g}$ in $100 \mathrm{~g})$ as exhibited in 20:50:30 when compared to FAMILA, the control. Protein is known to be deficient in pure cassava flours, which thus benefited from the fortification with cowpea leaves, the latter which increased the protein content of the formulated flours from $1.2 \%$ for pure cassava flours to 9 when $20 \%$ of cowpea leaves and $30 \%$ of millet were added to $50 \%$ cassava flour (Table 2). The increase in the nutritional composition of the flour is in agreement with the findings of Tharise et al. (2014), who found out that blending of varied crops into composite flours increases their nutritional quality. The blended cassava roots- 
Acid value of the acceptable composite formulated flours

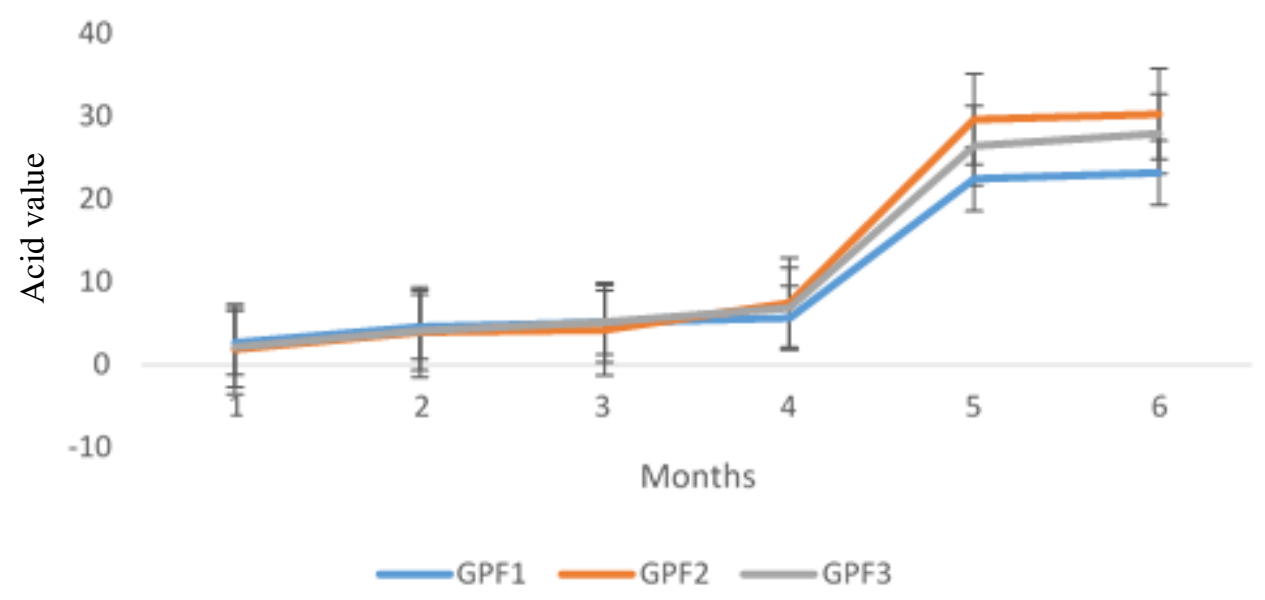

Figure 3. Acid value of the acceptable cassava-cowpea-millet composite flours under accelerated shelf-life.

cowpea leaves-millet- composite flour averaged $76 \%$ of the total protein required in a day if one consumed $100 \mathrm{~g}$ of the flour in normal physiological condition for an expectant woman.

The lack of positive change in protein content in the other two formulations (10:50:40 and 15:60:25) in which lower cowpea leaf proportions were added, suggests that the critical levels of protein required to mark a significant rise in the formulations was not attained by the levels of cowpea leaf flour added to both formulations. Hence, on the basis of protein nutrition, these two formulations may sub-optimally provide for pregnant women and children, for whom these formulations were intended.

The blended flours were high in crude fat, proving up to $3.5 \mathrm{~g}$ fat in $100 \mathrm{~g}$ (Table 2). This level of fat was due to the high fat content in cowpea leaves $(10.58 \%)$ and pearl millet $(4.12 \%)$ contained in their respective flours. These fat content values were in agreement with the levels reported by Ojokoh and Bello (2014). Flours which are based on cassava roots as the major ingredient had over $70.1 \mathrm{~g}$ carbohydrates content, and thus served to supply up to $100 \%$ of the total energy requirement.
The nutritious flour blends provided $89 \%$ of the daily required magnesium and on average above $40 \%$ of the daily required iron and zinc minerals (Table 3 ). The minerals are important for normal human growth and in most cases given to expectant women as supplements (Bibiana et al., 2014) and thus the provision of such minerals from legume, root tuber and cereal blended flour becomes a major contribution towards a food and nutrition secure Africa.

Sensory evaluation scores. The most appealing colour to the panellists was of the FAMILA and 20:50:30 at 5.18 \pm 1.35 and $5.18 \pm 1.48$, respectively. FAMILA flour was commonly retailed, and farmers were already consuming it. The 20:50:30 also had a perfect colour blend of the individual ingredient flours, and thus was the most acceptable to the farmers, among the formulations tested. An acceptable colour can, therefore, be obtained by blending cassava, cowpea leaves and millet flours.

In terms of mouth feel, composite flours showed no significant differences $(\mathrm{P}>0.05)$. However, the textures of the flours were significantly different $(\mathrm{P}<0.05)$, with formulation 20:50:30 having the highest score 
(5.52 \pm 1.54$)$, which was the most generally accepted flour (5.50 \pm 1.33$)$. The 20:50:30 had the highest protein content, and thus developed better cooking flavours. The combination of 20:50:30\% gave an optimised nutrient composition of the flour and the best combination for general consumer acceptability, according to this study.

Physico-chemical properties. The significant $(\mathrm{P}<0.05)$ differences in moisture contents in the four flour formulations after the $4^{\text {th }}$ and $5^{\text {th }}$ month could be attributed to hydrophilic nature of the different flour components. Cassava and millet flours have higher water absorption capacities compared to cowpea leaves. Cassava starch can absorb water up to double its weight as illustrated by Ayetigbo et al. (2018); while cowpea leaves have the lowest water absorption capacity. The good oil and water adsorption levels of cassava flours increases its preference for industrial and food use, as it can form better paste and confectionaries. The flours, therefore, can be stored in craft paper for a period of 3 months without significant variations in the moisture content, provided the flours are kept in dry conditions with low relative humidity (Olapade et al., 2014). However, the flours were able to store for five months confirming that blending of composite flours of cassava, cowpea leaves and millet improved the mixture quality (Tharise et al., 2014).

The absence of detectable peroxide in the three composition of flours over the storage duration, implies that the risk of spoilage due to fat in the flours would be minimal or not at all (Vanhanen and Savage, 2006). Although moisture content of the flours varied significantly during storage of the formulations, the levels of moisture contents were so low that the materials could be stored in craft paper for five months without major alterations in the quality of the flours. The findings are in agreement with those of Romani et al. (2016), who found out an association of increase of peroxide value with increase in water activity towards unity. The levels of moisture content in the samples were below $11 \%$, which resulted in very low water activity.

The fall in total viable microbial count (TVC) of all the flour formulation with time (Fig. 2), can be attributed to thermal shock to the micro-organism and the significant drop in water content of the samples (Fig. 2). The drop in moisture content translated into a reduction in water activity, and thus the evident drop in total counts. High moisture content of the flours promotes the sustenance of the TVC and thus affects the quality of the flours. As we promote the fortification of cassava flour with cowpea leaves and millet flours, it is advisable to use packages with low water vapour transmission rates and to always store the flours under dry conditions.

\section{CONCLUSION}

Composite flour of cassava roots- cowpea leaves-millet of ratio 50\% Cassava: 20\% cowpea leaves: $30 \%$ millet is a nutritious flour with as high as $9.0 \%$ protein content and generally accepted by the farmers of the Kenyan coast. The porridge, if made while minimising growth of yeast and moulds during the drying process, coupled with monitoring the flours through the milling process, can serve as a part of solution to the malnutrition of expectant women and childdren in Kenya. The flours do have a longer shelf-life of up to 6 months and thus can be kept in store for utilisation during the periods of scarcity in supply.

\section{ACKNOWLEDGEMENT}

The authors are grateful to the Mastercard Foundation and Regional Universities Forum for Capacity Building in Agriculture (RUFORUM) for funding research and publication cost through the Transforming African Agricultural Universities to meaningfully contribute to Africa's growth and development (TAGDev) Program. We also 
acknowledge the support of the University of Nairobi Food Science laboratory and Seed Enterprise Management Institute (SEMI) for the success of this work.

\section{REFERENCES}

Abong, G., Shibairo, S., Wanjekeche, E., Ogendo, J., Wambua, T., Lamuka, P.,Arama, P., Okoth, M., Mulwa, R., Kamidi, M., Zodoc, M. and Masha, C. 2016. Post-harvest practices, constraints and opportunities along cassava value chain in Kenya. Current Research in Nutrition and Food Science 4(2):114-126.

Adebiyi, J.A., Obadina, A.O., Adebo, O.A. and Kayitesi, E. 2017. Comparison of nutritional quality and sensory acceptability of biscuits obtained from native, fermented, and malted pearl millet (Pennisetum glaucum) flour. Food Chemistry 232:210-217.

Association of Official Analytical Chemists (AOAC). 2016. Official methods of analysis, 16th ed. Arlington, VA, USA: AOAC.

Ayetigbo, O., Latif, S., Abass, A. and Müller, J. 2018. Comparing characteristics of root, flour and starch of biofortified yellow-flesh and white-flesh cassava variants, and sustainability considerations: A review. Sustainability (Switzerland) 10(9):1-32.

Bibiana, I., Grace, N. and Julius, A. 2014. Quality evaluation of composite bread produced from wheat, maize and orange fleshed sweet potato flours. American Journal of Food Science and Technology 2(4):109-115.

FAO. 2003. FAO Food and Nutrition paper 77. Food energy - methods of anlysis and conversion factors.

IITA. 2016. Annual Report 2016. International Institute of Tropical Agriculture, Ibadan, Nigeria. pp 11-16.

Kayitesi, E., Duodu, K. G., Minnaar, A. and de Kock, H.L. 2010. Sensory quality of marama/sorghum composite porridges.
Journal of the Science of Food and Agriculture 90(12):2124-2132.

Lansakara, L.H.M.P.R., Liyanage, R., Perera, K.A., Wijewardana, I., Jayawardena, B.C. and Vidanarachchi, J.K. 2016. Nutritional composition and health related functional properties of Eleusine coracana (Finger Millet). Procedia Food Science 6:344-347.

Muoki, P.N., Kinnear, M., Emmambux, M.N. and de Kock, H.L. 2015. Effect of the addition of soy flour on sensory quality of extrusion and conventionally cooked cassava complementary porridges. Journal of the Science of Food and Agriculture 95(4):730-738.

Mwizerwa, H., Abong, G.O., Okoth, M., Ongol, M., Onyango, C. and Thavarajah, P. 2017. Effect of resistant cassava starch on quality parameters and sensory attributes of yoghurt. Current Research in Nutrition and Food Science 5(3):353-367.

Odhiambo, P., Gachanja, J., Gitonga-Karuoro, A., Nyangena, J., Munga, B., Kiriga, B. andWathuge, N. 2018. Kenya livestock market systems activity expanding and diversifying economic opportunities. Retrieved from www.kippra.org

Ojokoh, A.O. and Bello, B. 2014. Effect of fermentation on nutrient and anti-nutrient composition of millet (Pennisetum glaucum) and soyabean (Glycine max) blend flours. Journal of Life Sciences 8(8):668675.

Okonya, J.S. and Maass, B.L. 2014. Protein and iron composition of cowpea leaves: An evaluation of six cowpea varieties grown in Eastern Africa. African Journal of Food, Agriculture, Nutrition and Development 14(5):2129-2140.

Olapade, A. A., Babalola, Y.O. and Aworh, O.C. 2014. Quality attributes of fufu (fermented cassava) flour supplemented with Bambara flour. International Food Research Journal 21(5):2025-2032.

Onyango, S.O. 2019. Development of protein and mineral enriched cassava root-millet- 
cowpea leaves composite flour from selected popular cassava varieties in Kilifi and Taita-Taveta counties, Kenya. M.Sc. Dissertation. University of Nairobi, Kenya. 54-57pp

Romani, S., Rocculi, P., Tappi, S. and Dalla Rosa, M. 2016. Moisture adsorption behaviour of biscuit during storage investigated by using a new Dynamic Dewpoint method. Food Chemistry 195: 97-103.

Senevirathne, H.M., Rajasinghe, N.A. and Perera, D.A.M. 2016. Conspicuous consumption and rural poverty in farming community: An empirical investigation based on two DS divisions in Kurunegala District in Sri Lanka. Procedia Food Science 6:73 - 77.

Singh, E.S. 2016. Potential of millets: Nutrients composition and health benefits. Journal of Scientific and Innovative Research 5(2): 46-50.

Tharise, N., Julianti, E. and Nurminah, M. 2014. Evaluation of physico-chemical and functional properties of composite flour from cassava, rice, potato, soybean and xanthan gum as alternative of wheat flour. International Food Research Journal 21(4): 1641-1649.

Vanhanen, L. P. and Savage, G. P. 2006. The use of peroxide value as a measure of quality for walnut flour stored at five different temperatures using three different types of packaging. Food Chemistry 99(1): 64-69.

Zabat, M.A., Sano, W.H., Wurster, J.I., Cabral, D.J. and Belenky, P. 2018. Microbial community analysis of sauerkraut fermentation reveals a stable and rapidly established community. Foods 7(5). 